University of Rhode Island

DigitalCommons@URI

The Rhode Island Current Conditions Index

Economics

8-2018

\title{
Rhode Island Current Conditions Index - August 2018
}

Leonard Lardaro

University of Rhode Island, lardaro@uri.edu

Follow this and additional works at: https://digitalcommons.uri.edu/ricci

Part of the Econometrics Commons

Terms of Use

All rights reserved under copyright.

\section{Recommended Citation}

Lardaro, Leonard, "Rhode Island Current Conditions Index -- August 2018" (2018). The Rhode Island Current Conditions Index. Paper 176.

https://digitalcommons.uri.edu/ricci/176

This Newsletter is brought to you for free and open access by the Economics at DigitalCommons@URI. It has been accepted for inclusion in The Rhode Island Current Conditions Index by an authorized administrator of DigitalCommons@URI.For more information, please contact digitalcommons-group@uri.edu. 


\title{
CURRENT CONDITIONS
}

\section{LEONARD LARDARO, URI}

\author{
Available Online: http: / / www.Ilardaro.com/current.htm \\ Twitter: @ladardo
}

VOL XXV

NUMBER 9

AUG 2018

Thus far, the third quarter of 2018 hasn't exactly been a sign of great strength for Rhode Island. Nor has the year 2018 overall for that matter. The Current Conditions Index registered a series of very strong values in 2017, as six of the twelve months last year had CCI values of 92 (eleven of twelve indicators improved). The lowest value for that entire year was 75 , with three-quarters of the indicators improving. While we managed to hit a CCI value of 92 twice thus far this year, overall we have plateaued around last year's lowest value of 75 throughout most of this year.

Why this disparity? During 2016, Rhode Island experienced two quarters with highly negative rates of growth based on real GDP. That had the effect of lowering the base for economic comparisons throughout 2017, making them fairly easy to beat, often by wide margins. Enter 2018, when the statistical "sugar high" we got from comparisons based on depressed 2016 values no longer exists. It's back to reality once again. Comps are no longer that easily beat this year. As a result, the Current Conditions Index has only managed to exceed its year-earlier value twice through August. Furthermore, looking at $2018 \mathrm{CCI}$ values since their most recent peak in May, one trend clearly jumps out: Steadily decreasing CCI values. At this point, we have moved well beyond a period with one or two months of declining values. We can move beyond the "don't put too much weight on a

\begin{tabular}{|l|r|r|}
\hline \multicolumn{3}{|c|}{ CCI Indicators - \% Change } \\
\hline Government Employment & 0.0 & \\
\hline US Consumer Sentiment & -0.7 & \\
\hline Single-Unit Permits & -49.1 & \\
\hline Retail Sales & 3.0 & Y \\
\hline Employment Services Jobs & 4.0 & Y \\
\hline Priv. Serv-Prod Employment & 2.3 & Y \\
\hline Total Manufacturing Hours & 2.7 & Y \\
\hline Manufacturing Wage & 2.7 & Y \\
\hline Labor Force & 1.2 & Y \\
\hline Benefit Exhaustions & -9.6 & Y \\
\hline New Claims & 6.3 & \\
\hline Unemployment Rate (change) & -0.4 & Y \\
\hline \multicolumn{2}{|c|}{ Y = Improved Value } \\
\hline \multicolumn{2}{|c|}{} \\
\hline
\end{tabular}

single month's values" rule. As such, the progression of $\mathrm{CCI}$ values since August cannot be so easily dismissed. While the diminishing CCI values reflect that our cyclical economic momentum is slowing, we still continue to possess forward momentum. Consider two seemingly negative statistics: Persona income growth for Q2 of 2018 gave Rhode Island a rank of \#49 - due to more difficult comps; Payroll employment for August in RI fell - likely just a statistical fluke, as the earlier months had very likely overstated job growth. Several other key indicators such as resident employment continue to improve, likely the LO of FILO continuing. The recent slowing of CCI values, however, might (key word) be a signal that we are about to re-enter the FI portion of FILO. Is the Rhode Island Red Canary in a Coal Mine becoming woozy? Something we can't entirely dismiss, since with our FILO status, our economy peaks anywhere from twelve to eighteen months ahead of the national economy. We'll have to wait and see.

The August Current Conditions Index value fell to its lowest value thus far in 2018,67, as only eight indicators improved relative to a year ago, the sixth time this year the CCI has failed to exceed its year-earlier value. Only two of the five leading indicators contained in the CCI improved this month, although all five had difficult comps from a year ago. New Claims rose again in August $(+6.3 \%)$, further postponing its resumption of a downtrend. Rhode Island's goods-producing sector's performance was again mixed. Total Manufacturing Hours, a proxy for manufacturing output, an important element of Rhode Island's strength over the past two years, rose more slowly in August $(+2.7 \%)$ based improvements in both employment and the length of the workweek. Single-Unit Permits, which reflect new home construction, fell very sharply $(-49.1 \%)$, its seventh decline in the past ten months. Employment Service Jobs, a leading labor market indicator that includes temporary employment, managed to improve in August $(+4.0 \%)$ after remaining unchanged last month. US Consumer Sentiment fell in August $(-0.7 \%)$, following six consecutive improvements.

As has been true throughout 2018, the "left behind" indicators continued to improve, sustaining uptrends that began in January. The labor force participation rate, the percentage of our resident population in the labor force, remained at its highest level since March of 2016: 64.9 percent. The employment rate, the percentage of the resident population that is employed, attained its highest value since late 2008: 62.3 percent. While both remain well below their prior cyclical highs (see table below),

their August and 2018 performances overall are encouraging.

Retail Sales grew again $(+3.0 \%)$, Government Employment remained unchanged from its level a year ago, Private ServiceProducing Employment growth remained above one percent $(+2.3 \%)$, Benefit Exhaustions, the most timely measure of longer-term unemployment, fell sharply and the Unemployment Rate fell for the right reason (a rising Labor Force).

$\begin{array}{rrr}\text { LABOR FORCE; } & \text { Aug 2018 } & \text { Peak (1/2007) } \\ \text { Participation Rate } & 64.9 \% & 68.6 \% \\ \text { Employment Rate } & 62.3 \% & 65.4 \%\end{array}$

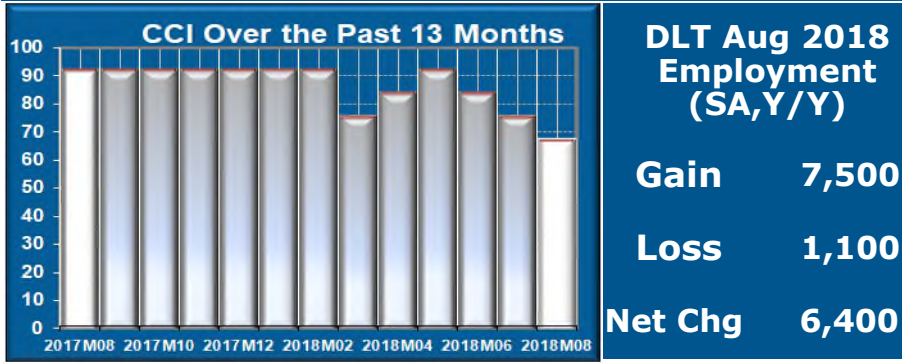

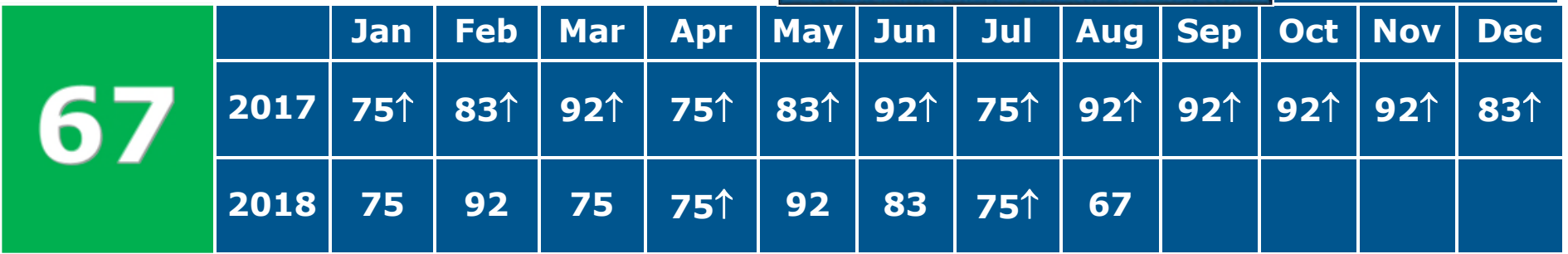

Gopyright @ 2017, 2018 Leonard Lardaro, Ph.D. All rights reserved. 